\title{
Quality of Life of People with Thoracic Outlet Syndrome after Surgery
}

\section{Qualidade de vida de pessoas com síndrome do desfiladeiro torácico após a cirurgia}

\author{
Silvio Luis Frandoloso ${ }^{1}$ Henrique Boell Pimentel ${ }^{2}$ \\ Natalia Veronez da Cunha Bellinati ${ }^{3}$
}

Address for correspondence Natalia Veronez da Cunha Bellinati, MD, Programa de Pós-Graduação em Ambiente e Saúde, Universidade do Planalto Catarinense (Uniplac), Av. Castelo Branco 170, Bairro Universitário, Lages, SC, 88509-900, Brasil (e-mail: nat_cunha@hotmail.com).

\author{
Keywords \\ - repetitive strain injury \\ - chronic pain \\ - surgery \\ - multidisciplinary \\ team
}

Purpose To evaluate the quality of life of patients with neurogenic thoracic outlet syndrome (N-TOS) who underwent surgery via the supraclavicular approach.

Method Sociodemographic and clinical data were collected, and an evaluation of the pain and quality of life of 29 patients was performed.

Results The average age of the patients was 42 years, and most of them were female. All of them had one or more associated pathologies. They all worked in occupations that involved repetitive movement of the upper limbs. The evaluation of the degree of pain showed that the pain remains preponderant and incapacitating in the life of these individuals, who consequently enjoy a low quality of life.

Conclusion These patients presented low quality of life, with persistent pain probably resulting from the associated pathologies, in addition to their psychosocial context. Thus, in order to treat the TOS, an intervention of a multidisciplinary team with a holistic view of the patient is required. received

September 18, 2017 accepted

November 13, 2017

published online

December 15, 2017
DOI https://doi.org/

10.1055/s-0037-1615258. ISSN 0103-5355.
Copyright $(2018$ by Thieme Revinter

Publicações Ltda, Rio de Janeiro, Brazil
License terms

(ㄷ) (i) $\ominus$ (\$) 


\section{Resumo}

\author{
Palavras-chave \\ - lesão por esforço \\ repetitivo \\ - dor crônica \\ - cirurgia \\ - equipe \\ multidisciplinar
}

Objetivo Avaliar a qualidade de vida de pacientes com síndrome do desfiladeiro torácico (SDT) do tipo neurogênico submetidos a cirurgia por via supraclavicular. Metodologia Foram coletados dados sociodemográficos e clínicos, e foram avaliadas a dor e a qualidade de vida de 29 pacientes.

Resultados Os pacientes tinham idade média de 42 anos, sendo a maioria do sexo feminino, e todos com uma ou mais patologias associadas. Todas as ocupações profissionais exercidas envolviam movimentos repetitivos de membros superiores. A avaliação do quadro álgico evidenciou que a dor ainda permanece preponderante e incapacitante na vida desses indivíduos, que, consequentemente, apresentam baixa qualidade de vida.

Conclusão Estes pacientes apresentaram baixa qualidade de vida, com persistência da dor, provavelmente em decorrência das patologias associadas, além do contexto psicossocial. Desse modo, para o tratamento da SDT, faz-se necessária a intervenção de uma equipe multidisciplinar com visão holística do paciente.

\section{Introduction}

An individual's perception of his/her own well-being in the areas of work, culture and values - including personal goals, expectations and personal interests - defines health-related quality of life. ${ }^{1}$ This is a subjective concept inherent to individual perceptions. It encompasses many dimensions, without focusing only on the worries regarding health. ${ }^{2}$

Pain may produce a negative impact on the quality of life of individuals, affecting their attention, causing physiological dysfunctions and disorders from an emotional, social and professional standpoint, as well as sleeping disorders, physical and mental frailty, social isolation, difficulty to eat, reduction of daily activities and absenteeism. ${ }^{3}$

Chronic pain affects $\sim 10$ million individuals around the world. In addition, $14 \%$ of chronic pain is related to the musculoskeletal joints. ${ }^{4}$ Musculoskeletal disorders are among the most frequent causes of work disability in Brazil. Repetitive strain injury (RSI) or work-related osteomuscular disorders (WRODs) are the ones that affect workers the most. ${ }^{5}$ Repetitive strain injury and WRODs are identified by repetitive movements in the work environment and by the workers' individual characteristics, such as inadequate posture, genetic predisposition, weight and relationship with work, among others. ${ }^{6}$

Thoracic Outlet Syndrome (TOS) is a type of RSI/WROD characterized by neurogenic symptoms that involve the upper limbs. It affects young people, mostly women, and, in a few cases, it may cause disability. ${ }^{7}$ It is considered one of the most controversial syndromes among the ones that cause pain in the upper limbs, and it is at times associated with surgical interventions, even when there are no clear evidences of a true TOS. ${ }^{8-10}$

Patients diagnosed with TOS must first undergo conservative treatment that involves strengthening, stretching, and postural correction exercises. And, when possible, they must reduce the intensity of their manual activities/tasks. Such measures may help in the recovery and stop the progression of the disorder. ${ }^{8-10}$ Surgical treatment, on the other hand, is reserved for those people who remain in severe and refractory chronic pain for longer than three months, which compromises the patients' quality of life. ${ }^{11}$ Thus, considering chronic pain as a disabling symptom for the neurogenic TOS patient, the purpose of this study is to evaluate the quality of life of patients who underwent supraclavicular surgery, and to evaluate whether there was an improvement in the patients' degree of pain.

\section{Method}

Descriptive, quantitative and retrospective studies were conducted with neurogenic thoracic outlet syndrome patients who underwent a surgical procedure via the supraclavicular approach in the period between 2008 and 2015. The collection of data was performed in two steps: firstly, we selected the patients using information from the medical charts of the neurosurgeon's office (sociodemographic data and preoperative information), and secondly, we performed and in-person consultation to assess pain and quality of life after surgery.

The selection criteria were: patients over 18 years of age, who had undergone at least 1 year of a conservative treatment for the syndrome (physiotherapy and painkillers) without improvement of the clinical condition and with a postoperative period of at least 6 months of evolution. After that, the selected patients were contacted by email and/or phone, and those who agreed to participate had to attend an evaluation at the medical office at a previously scheduled time, according to their availability. In a reserved room, two medical academics performed the collection of data.

All procedures were standardized, including the collection of data and the strategies to approach the participants for the research.

This study was approved by the Ethics and Research Committee of our institution (CAE no. 48351015.6.0000.5368).

\section{Research data}

Sociodemographic data such as age, sex and occupation were collected from the patients' medical charts, as well as data on clinical tests and associated pathologies. 
The selected patients were classified according to the type of thoracic duct syndrome presented. The syndrome was classified as typical and atypical and according to an adaptation in the classification described by Franklin $(2015)^{8}$ due to regional diagnostic difficulties.

Typical neurogenic TOS: the patients present with neurogenic symptoms, at least five positive provocative maneuvers, and at least one positive neurodiagnostic test (electroneuromyography; angiography by magnetic resonance of the subclavian vessels with Adson maneuver; or echo-Doppler of the subclavian vessels with Adson maneuver and magnetic resonance of the brachial plexus) with lower plexus lesion signs (C8/T1).

Atypical neurogenic TOS: the patients present with neurogenic symptoms, at least five positive provocative maneuvers, and no positive results in the neurodiagnostic tests mentioned before.

During the evaluation at the physician's office, the medical academics performed the qualitative and quantitative evaluation of pain, which was based on the patients' verbal descriptions in the Brazilian short-form version of the McGill pain questionnaire, ${ }^{12}$ which is made up of three parts: description of pain, present pain intensity (PPI) and index of intensity of pain through the visual analog scale for pain (VAS Pain). In the same occasion, the evaluation of the quality of life regarding health by means of the 36-item short-form (SF-36) health survey, with a validated adaptation to the Portuguese language was performed. ${ }^{13}$

\section{Statistical Analysis}

Data were analyzed with the Prism (GraphPad, La Jolla, CA, US) software, version 5.0. The data collected were then submitted to a descriptive statistical analysis (arithmetic mean and standard deviation) and the differences among the data were identified using one-way analysis of variance (ANOVA) followed by the Tukey post-hoc test. The differences were considered statistically significant for values of $p \leq 0.05$.

\section{Results}

Based on the survey of the medical charts of the patients who had been submitted to thoracic outlet surgery by the supraclavicular approach between the years of 2008 and 2015, a total of 52 patients were identified and contacted by email and/or phone. Of these, only 20 patients did not answer the email and/or phone contact, with a total of 32 patients achieved. However, three among those initially selected were excluded because they did not meet the research criteria (one did not agree to participate, and two of them were in a postoperative period lower than six months). Thus, 29 patients with neurogenic TOS submitted to surgery via the supraclavicular approach participated in this study.

The average age of the participants was 42 years (25-54 years), and 25 patients were female. As for professional occupations, eight of them were farmers, nine were housekeepers, four were production assistants, two were shop owners, two were electricians, one was an office assistant, one was a clerk, and one was a self-employed professional.
Regarding the period of the surgeries, most of them were performed in the years 2015 (13) and 2013 (6), and the others in 2008 (2), 2009 (2), 2010 (3), 2011 (2) and 2012 (1).

Regarding the classification, three patients had atypical neurogenic TOS that was positive on the neurologic tests, with five to nine positive provocative maneuvers, and no positive result in the neurodiagnostic tests; nevertheless, these patients opted for the surgical procedure.

The other 26 patients had typical neurogenic TOS that was positive on the neurologic tests, with five to nine positive provocative maneuvers and at least one positive result in the neurodiagnostic tests. All patients in the study underwent electroneuromyography and angiography by magnetic resonance of the subclavian vessels (resulting in 25 positive results), with Adson maneuver tests (resulting in 7 positive results). A total of 16 patients underwent the echo-Doppler of the subclavian vessels with Adson maneuver, which resulted in 13 positive results. Only two patients underwent magnetic resonance of the brachial plexus, and both results were positive.

Postoperative complications included two cases of seroma and surgical incision pain, one thoracic duct lesion, which improved after subcutaneous drainage with Penrose drains, and two hematomas below the surgical incision area. The other patients did not present any complications. Only three patients did not undergo physiotherapy after the surgeries.

Regarding the patients' return to work, 21 out of the sample of 29 failed to resume their work activities: 18 remained on medical leave, and 3 patients were retired for length of service.

All participants in the study presented one or more associated pathologies, such as: contralateral TOS, unilateral or bilateral shoulder cuff syndrome, bilateral or unilateral carpal tunnel syndrome, cervical disk herniation, epicondylitis, lumbar disc herniation and/or lumbar spine segmental instability.

Data regarding the intensity of the pain and the quality of life were evaluated with the Brazilian short-form version of the McGill pain questionnaire. The first part of the questionnaire refers to the description of pain, which was presented through the percentage of choice of each word ( - Table 1 ). It should be noted that 9 out of 15 words that qualify the painful experience were described by most patients as severe.

No differences were found between the median rate of evaluation of pain in the sensory, affective and total aspects, as all of them were considered severe (-Table $\mathbf{2}$ ).

In relation to the evaluation of the global PPI, at the time of the application of the questionnaire, the patients reported severe pain $(2.72 \pm 1.51, n=29)$. On the other hand, pain intensity after the surgical procedure, which was estimated with the VAS Pain, was of $5.8 \pm 2.9$.

The analysis of the quality of life scale (QoLS) scores, according to the categories generated from the application of the instrument, shows a mostly low quality of life for these patients, who presented a median score below 50 .

The median scores of the dimensions evaluated by the SF-36 were presented in -Table 3, where the dimensions with lower values were caused by limitations due to physical aspects, followed by limitations due to emotional aspects and to pain. 
4 Neurogenic Thoracic Outlet Syndrome Frandoloso et al.

Table 1 Percentage of choice of each word in the Brazilian short-form version of the McGill pain questionnaire for TOS patients submitted to surgery

\begin{tabular}{|l|l|l|l|l|}
\hline & $\begin{array}{l}\text { No } \\
(\%)\end{array}$ & $\begin{array}{l}\text { Weak } \\
(\%)\end{array}$ & $\begin{array}{l}\text { Mild } \\
(\%)\end{array}$ & $\begin{array}{l}\text { Severe } \\
(\%)\end{array}$ \\
\hline Throbbing & 20.7 & 10.3 & 20.7 & 48.3 \\
\hline Shooting & 20.7 & 10.3 & 27.6 & 41.4 \\
\hline Stabbing & 41.4 & 3.4 & 17.2 & 37.9 \\
\hline Sharp & 62.1 & 6.9 & 17.2 & 13.8 \\
\hline Cramping & 41.4 & 10.3 & 13.8 & 34.5 \\
\hline Gnawing & 72.4 & 3.4 & 10.3 & 13.8 \\
\hline Hot & 31.0 & 6.9 & 27.6 & 34.5 \\
\hline Aching & 24.1 & 10.3 & 31.0 & 34.5 \\
\hline Heavy & 30.7 & 6.9 & 27.6 & 44.8 \\
\hline Tender & 37.9 & 17.2 & 20.7 & 24.1 \\
\hline Splitting & 27.6 & 13.8 & 20.7 & 37.9 \\
\hline Tiring & 17.2 & 6.9 & 20.7 & 55.2 \\
\hline Sickening & 44.8 & 6.9 & 24.1 & 24.1 \\
\hline Fearful & 24.1 & 6.9 & 24.1 & 44.8 \\
\hline Punishing & 27.6 & 13.8 & 17.2 & 41.4 \\
\hline
\end{tabular}

Abbreviation: TOS, thoracic outlet syndrome.

Table 2 Mean scores for sensory, affective and total aspects of the Brazilian short-form version of the McGill pain questionnaire filled out by patients with TOS submitted to surgery $(p=0.95)$

\begin{tabular}{|l|l|l|}
\hline Rate & Mean & N \\
\hline Sensory & $2.95 \pm 0.96$ & 29 \\
\hline Affective & $2.97 \pm 0.97$ & 29 \\
\hline Total & $2.90 \pm 0.92$ & 29 \\
\hline
\end{tabular}

Abbreviation: TOS, thoracic outlet syndrome.

Table 3 Scores for dimensions in the SF-36 questionnaire filled out by patients with TOS submitted to surgery

\begin{tabular}{|l|l|l|l|l|}
\hline & Mean & SD & Min. & Max. \\
\hline Functional capacity & 47 & 32.6 & 0 & 100 \\
\hline $\begin{array}{l}\text { Limitation due to } \\
\text { physical aspects }\end{array}$ & 24 & 32.4 & 0 & 100 \\
\hline Pain & 34 & 29.1 & 0 & 100 \\
\hline General health condition & 40 & 15.9 & 5 & 72 \\
\hline Vitality & 38 & 21.8 & 5 & 85 \\
\hline Social aspects & 47 & 31.6 & 0 & 100 \\
\hline $\begin{array}{l}\text { Limitation due to } \\
\text { emotional aspects }\end{array}$ & 26 & 38.2 & 0 & 100 \\
\hline Mental health & 42 & 22.8 & 0 & 96 \\
\hline
\end{tabular}

Abbreviations: Max., maximum; Min., minimum; SD, standard deviation; SF-36, 36-item short-form health survey; TOS, thoracic outlet syndrome.

\section{Discussion}

Chronic pain may have negative consequences in the quality of life of people. ${ }^{14}$ Considering it as an incapacitating symptom for the patient with TOS, this study evaluated the quality of life of patients who underwent surgery via the supraclavicular approach. The 29 patients who had undergone surgery more than six months before the study were evaluated, and they presented low quality of life and persistence of severe pain. Thoracic Outlet Syndrome is difficult to diagnose, ${ }^{15}$ and there is no evidence that the supraclavicular surgery reduces the pain in patients with this syndrome, who classify it as incapacitating and irritating, with a great influence over their quality of life.

Most of the participants in the research were females of working age. Such predominance probably occurs due to women's propensity to seek health care, be it at outpatient clinics or at hospitals, ${ }^{16}$ as well as due to their long working hours, which include housework and work outside the home. ${ }^{17}$ Such long working hours might result in a RSI/ WROD, with recurring painful affections resulting from repetitive movements and, consequently, limitations by physical aspects.

Work performing repetitive movements causes the chronic pain symptoms and reduction of muscle strength, incapacitating an individual to do his/her job or house chores. Deconditioned muscles due to any associated pathology are more prone to suffer lesions during physical activities. Such lesions may cause more pain, further incapacitating the individual and limiting him/her to a sedentary lifestyle and one of physical immobility. $^{18}$

The patients evaluated had professional occupations such as teachers, cleaners, inventory controllers, and farmers, which involve repetitive movements of the upper limbs. The etiology of the syndrome is connected to the patient's occupation, such as those that involve overload, flexion and abduction positions of the upper limbs above the height of the shoulders or hyperextension of the shoulders, compression on the shoulder or of the shoulder against an object, and lateral flexion of the neck. ${ }^{19}$ Workers from the most varied fields of activity are submitted to work conditions that cause and/or aggravate RSI/WROD-related conditions. ${ }^{20}$

The patients in this study attributed the development of their pain to manual labor, as their jobs involved repetitive movements, always in the same position. They reported that, at the end of the workday, they felt their arms were numb, and they felt a sensation of fatigue, but they attributed that to mismanagement of daily tasks. Thus, they postponed seeking medical attention and made use of over-the-counter painkillers, which helped improve their condition, but that no longer had any effect over a period of time. Ergonomics is of the utmost importance, at any company, in order for workers to perform a certain task. To this end, details such as time, breaks, relaxation exercises, management, and complexity of task should be observed to allow the workers to sustain the quality of their work. Ergonomics requires that a task be adapted to the employee within the limits and skills of this human being, and not the other way around. In this sense, 
those employees might be compromised as regards RSI/ WRMD. ${ }^{21}$

Most of the patients did not present surgical complications, and only three of them did not undergo the prescribed postoperative physiotherapy. However, 21 of them did not return to work. The presence of pain, even after surgery, made it impossible for them to return to work and perform the movements with their upper limbs. The patients' return to work depends on the type of surgery and when the rehabilitation process starts, as most of them are able to return to work with a light workload within 4 to 6 weeks, and to regular work within 10 to 12 weeks after surgery. ${ }^{8}$ However, the authors of the present study report that most of the patients on sick leave do not present good results after a year of surgery, which explains the low level of return to work among the sample of this study.

An aggravating factor for the patients in this study was that all of them had one or more associated musculoskeletal pathologies, which may prolong their pain. In addition, that may be considered an extra factor of confusion in relation to the pain described by the patient. The neuro-musculoskeletal system is known to be vital for survival, so we can perform our daily activities and the skilled tasks required at work. The predisposing or causal factors of osteomuscular disorders have been grouped as biomechanical and psychosocial factors, and stress is considered one of the means by which psychosocial factors affect osteomuscular health. ${ }^{22}$

An evaluation of the intensity of the pain after the surgical procedure by means of the Brazilian short-form version of the McGill pain questionnaire showed that the pain remained preponderant and debilitating in the life of those individuals, and, consequently, the result of the SF-36 questionnaire generally showed low quality of life in these patients. A lower score can be observed for limitations due to physical aspects, followed by limitations due to emotional aspects and to pain. According to Ciconelli (1997), ${ }^{13}$ the "limitation due to physical aspects" component in the SF-36 questionnaire is intended to assess the extent to which physical limitations can interfere in the daily life of an individual. The patients in the present study reported limitations in their day-to-day tasks, such as hanging clothes on the line, cleaning the house, or even combing their hair or taking a shower. Such limitations were connected to the feeling of uselessness by the patients, which may explain the low score in the emotional aspects. The symptoms of RSI/WRMD affect the life of a worker in an aspect that goes beyond the work environment, as it affects the personal life of individuals. ${ }^{23}$

Pain might determine changes in sleep, appetite and libido, in addition to causing irritability, reduction of energy and concentration, difficulty to engage socially, and low interaction in the work and family environments. ${ }^{24}$

It is suggested that psychological disorders such as anxiety and depression, for example, should also be investigated in patients with chronic pain, as they may be associated with the continuity (chronicity) of the symptoms. Chronic pain, mainly when associated to a high degree of disability, is no longer solely a medical problem. ${ }^{25}$ Patients suffering from depression and anxiety often report high levels of physical symptoms such as pain; on the other hand, many patients with musculoskeletal disorders complain that their pain caused their depression. ${ }^{26}$ The feeling of incapacitation and uselessness reported by many patients may have interfered with their emotional state.

Therefore, the patient should be examined by a multidisciplinary team including a surgeon, a neurologist and a physiotherapist, and possibly be sent to a psychologist or psychiatrist in cases of severe or chronic pain. This may facilitate the return to work of these patients. In addition, it is necessary to evaluate other factors such as obesity and postural changes, which are also associated with TOS. ${ }^{27}$

Pain is the fifth vital sign, and it requires a measurement of the symptoms. The International Association for the Study of Pain (IASP) defines pain as "an unpleasant sensory and emotional experience that is associated with actual or potential tissue damage, or which is described as such." Although this definition may be rather succinct, it covers the complexity of the processing of pain, as it does not regard pain only as a nociceptive process; it also shows the several psychological influences that are related to pain. ${ }^{28}$ Thus, pain may influence negatively people's quality of life, in their emotional characteristics, in their daily motivation, in behavioral-cognitive aspects, as well as in their work.

Furthermore, decrease in the quality of life regarding the physical domain may affect maintenance of the patients' autonomy, which may limit his/her performance in daily activities, making him/her dependent in his/her social, economic and cultural contexts. ${ }^{29}$

It should be noted how difficult it was to recruit patients to participate in this study, as 52 medical charts were selected, but only $55.7 \%$ of the patients selected participated in the study, which may be considered a bias inherent to a retrospective study. The patients who were contacted and participated in the study may represent those who still had some proximity the doctor's office they were still suffering from pain.

In conclusion, patients with neurogenic TOS who were submitted to a surgery via the supraclavicular approach presented low quality of life because of physical, emotional and pain limitations. Persistence of pain occurred probably due to associated pathologies, as well as because of the psychosocial context, which may be considered a factor of confusion in relation to the pain described by a patient. Thus, in order to treat neurogenic TOS, an intervention of a multidisciplinary team with a holistic view of the patient is required, as well as adaptations of the working conditions of the people affected by this syndrome.

Conflicts of Interest

The authors have no conflicts of interest to declare.

\section{Support}

Henrique Boell Pimentel received financial support from Pibic/CNPq Uniplac - 2015/2016 (Edict no. 097/2015).

\section{Acknowledgment}

The authors are grateful to the patients for their fundamental cooperation during the study. 


\section{References}

1 Orsel S, Akdemir A, Dağ I. The sensitivity of quality-of-life scale WHOQOL-100 to psychopathological measures in schizophrenia. Compr Psychiatry 2004;45(01):57-61

2 Landeiro GMB, Pedrozo CCR, Gomes MJ, Oliveira ERA. Systematic review of studies on quality of life indexed on the SciELO database. Cien Saude Colet 2011;16(10):4257-4266

3 Silva JÁ, Ribeiro Filho NP. A dor, um problema psicofísico. Rev Dor 2011;12:138-151

4 Cunha LL, Mayrink WC. Influência da dor crônica na qualidade de vida de idosos. Rev Dor 2011;12:120-124

5 Vieira ER, Albuquerque-Oliveira PR, Barbosa-Branco A. Work disability benefits due to musculoskeletal disorders among Brazilian private sector workers. BMJ Open 2011;1(01):e000003

6 Barbosa MAS, Santos RM, Trezza MCSF. A vida do trabalhador antes e após a Lesão por Esforço Repetitivo (LER) e Doença Osteomuscular Relacionada ao Trabalho (DORT). Rev Bras Enf, Brasília 2007;60:491-496

7 Durán Mariño JL, Pérez Carballo E, Pena Holguín J, Paulín Vera CM, Hollstein Cruz PH, García Colodro JM. Resultados del tratamento quirúrgico del síndrome del estrecho torácico. Angiologia 2014; 66:119-124

8 Franklin GM. Work-related neurogenic thoracic outlet syndrome: diagnosis and treatment. Phys Med Rehabil Clin N Am 2015;26 (03):551-561

9 Laulan J. Thoracic outlet syndromes. The so-called "neurogenic types". Hand Surg Rehabil 2016;35(03):155-164

10 Peek J, Vos CG, Ünlü Ç, Van De Pavoordt HDWM, Van Den Akker PJ, Vries JPPM. Outcome of surgical treatment for thoracic outlet syndrome: systematic review and meta-analysis. Ann Vasc Surg, Amsterdam; 2016

11 Dalbayrak S, Yaman O, Yilmaz M, Yilmaz T. Supraclavicular surgical approach for thoracic outlet syndrome: 10 years of experience. Turk Neurosurg 2014;24(06):867-872

12 Castro CES. A formulação linguística da dor - versão brasileira do questionário McGill de Dor. [Dissertação]. São Carlos - Centro de Ciências Biológicas e da Saúde, Universidade Federal de São Carlos 1999

13 Ciconelli RM. Tradução para o português e validação do questionário genérico de avaliação de qualidade de vida Medical Outcomes Study 36-Item Short-form Health Survey (SF-36). [Tese]. São Paulo: Universidade Federal de São Paulo; 1997
14 Castro MMC. Comorbidade de sintomas ansiosos e depressivos em pacientes com dor crônica e o impacto sobre a qualidade de vida. Arch Clin Psychiatry 2011;38:126-129

15 Povlsen B, Hansson T, Povlsen SD. Treatment for thoracic outlet syndrome. Cochrane Database Syst Rev 2014;(11):CD007218

16 Pimentel IRS, Coelho BC, Lima JC, et al. Caracterização da demanda em uma Unidade de Saúde da Família. Rev Bras Med Fam Com 2011;6:175-181

17 França AL, Schimansk E. Mulher, trabalho e família: uma análise sobre a dupla jornada feminina e seus reflexos no âmbito familiar. Emancipação 2009;9:65-78

18 Cardoso FdeS, Curtolo M, Natour J, Lombardi Júnior I. Avaliação da qualidade de vida, força muscular e capacidade funcional em pacientes com fibromialgia. Rev Bras Reumatol 2011;51(04):338-343, 349-350

19 Silva CF, Silva M. Prevalência da Síndrome do Desfiladeiro em professores do Ensino Médio. Rev Ter Man 2011;9:86-91

20 Brasil. Ministério da Saúde. Secretaria de Atenção a Saúde. Protocolo Clínico e Diretrizes Terapêuticas - dor crônica. Portaria SAS/MS n. 1.083, de 02 de outubro de 2012. Brasília: Ministério da Saúde; 2012

21 Negri JR, Cerveny GCO, Montebelo MIL, Teodori RM. Perfil sociodemográfico e ocupacional de trabalhadores com LER/DORT: estudo epidemiológico. Rev Bai Saude Publica 2014;38:555-570

22 Pinheiro FA, Troccoli BT, Paz MGT. Preditores psicossociais de sintomas osteomusculares: a importância das relações de mediação e moderação. Psicol Reflex Crit 2006;19:142-150

23 Dosea GS, Da Cunha Oliveira CC, Lima SO. Percepção da qualidade de vida em portadores de distúrbios osteomusculares relacionados ao trabalho. Cienc Cuid Saude 2016;15:482-488

24 Kreling MCGD, da Cruz DA, Pimenta CAM. Prevalence of chronic pain in adult workers. Rev Bras Enferm 2006;59(04):509-513

25 Oliveira JT. Aspectos Comportamentais das Síndromes de Dor Crônica. Arq Neuropsiquiatr 2000;58(2A):360-365

26 Henderson M, Bass C. Chronic pain: the role of psychosocial factors in common musculoskeletal disorders. Psychiatry 2006;5:52-56

27 Thompson JF. Thoracic outlet syndromes. Surgery, Amsterdam 2016;34:198-202

28 IASP. International Association for the Study of Pain. Guia para o Tratamento da Dor em Contextos de Poucos Recursos. Seattle: IASP; 2010:418p

29 Lung FW, Huang YL, Shu BC, Lee FY. Parental rearing style, premorbid personality, mental health, and quality of life in chronic regional pain: A causal analysis. Compr Psychiatry 2004;45(03):206-212 